\title{
Nephrotoxic and in vivo Antioxidant Effects of Citrullus Lanatus Seed Extract
}

\author{
Abu Osahon Daniel ${ }^{1 *}$, Imafidon Kate Evbu ${ }^{1}$ and Obayuwana Osemena ${ }^{2}$ \\ ${ }^{1}$ Department of Biochemistry, Faculty of Life Sciences, University of Benin, Nigeria \\ ${ }^{2}$ Department of Science Laboratory Technology, Faculty of Life Sciences, University of Benin, Nigeria
}

*Corresponding author: Abu Osahon Daniel, Department of Biochemistry, Faculty of Life Sciences, University of Benin,

Benin City, Nigeria

\section{ARTICLE INFO}

Received: 慧 February 09, 2021

Published: 㓞 February 15, 2021

Citation: Abu Osahon Daniel, Imafidon Kate Evbu, Obayuwana Osemena. Nephrotoxic and in vivo Antioxidant Effects of Citrullus Lanatus Seed Extract. Biomed J Sci \& Tech Res 33(5)-2021. BJSTR. MS.ID.005473.

Keywords: Antioxidant Enzymes; Citrullus Lanatus; Electrolytes; Nephrotoxicity; Oxidative Stress

Abbreviations: SOD: Superoxide Dismutase; ROS: Reactive Oxygen Species; BDH: British Drug House; GSH: Reduced Glutathione; MDA: Malondialdehyde

\section{ABSTRACT}

Background: Citrullus lanatus seeds are known to be highly nutritious, and rich sources of phenolic compounds. They are usually milled into flour and used for making sauces, snacks, and cooking oil.

Aim: To investigate the in vivo antioxidant capacity and effect of sub-chronic doses of methanol extract of $C$. lanatus seed on renal function.

Methods: Adult male Wistar rats $(\mathrm{n}=35)$ weighing 130 to $170 \mathrm{~g}$ (mean weight $=150$ $\pm 20 \mathrm{~g}$ ) were randomly assigned to seven groups of five rats each: normal control, Tween 80 control, and five treatment groups. Rats in the treatment groups received graded doses of the extract (10 - $5000 \mathrm{mg} / \mathrm{kg}$ body weight, bwt) orally for 35 days. Indices of renal function and oxidative stress were assayed.

Results: The absolute and relative weights of kidneys of rats in each group were not significantly affected by extract treatment $(\mathrm{p}>0.05)$. There were significant increases in the final body weight and percentage weight increase in the treatment groups, relative to normal control group $(\mathrm{p}<0.05)$. Methanol extract of $C$. lanatus seed did not significantly alter the levels of electrolytes, creatinine, malondialdehyde (MDA) and reduced glutathione (GSH), as well as activity of Superoxide Dismutase (SOD) among the groups ( $p>0.05$ ). Moreover, Tween 80 significantly increased the levels of bicarbonate ion, urea and urea/creatinine ratio $(\mathrm{p}<0.05)$.

Conclusion: These results show that methanol extract of Citrullus lanatus seed is not nephrotoxic and possesses high antioxidant activity in vivo.

\section{Introduction}

Citrullus lanatus (watermelon) seeds are often discarded after consumption of the pulp [1]. These seeds are sources of phytochemicals such as phenols, alkaloids and saponins. It was only recently attention was given to the possible utilization of C. lanatus seeds in the production of new ingredients for food enrichment [2,3]. Citrullus lanatus seeds are milled into flour and used to prepare snacks and sauces. The oil is used for cooking and production of cosmetics [4]. The seeds of this medicinal plant are rich in protein, vitamins, minerals and fat $[5,6]$. Secondary metabolites present in $C$. lanatus seeds are responsible for its many pharmacological activities, such as analgesic, anti-inflammatory, anti-ulcer, antioxidant, as well as hepatoprotective properties [79]. Antioxidants are substances/molecules that have the capacity to inhibit or counteract the damaging effects of oxidation in animal and plant tissues [10]. Reactive Oxygen Species (ROS) cause lipid peroxidation and oxidative stress which damage biological macromolecules such as proteins, lipids and DNA [11-13].

Oxidative stress has been linked with chronic diseases such as cancer, diabetes mellitus, aging and other degenerative diseases [4]. Phenolic compounds are the most active natural antioxidants in plants [14]. Their free radical scavenging ability is due to the presence of hydroxyl group which is directly bonded with the aromatic (phenyl) ring $[15,16]$. Equilibrium between the levels of ROS and antioxidants is vital for the elimination of the adverse effects of oxidative stress in biological systems [17-21]. Lipid peroxidation-induced renal injury is often initiated by free radical 
attack on membrane polyunsaturated fatty acids leading to their transformation to alkanes and reactive aldehyde such as MDA [22]. Oxidative stress occurs when the production of harmful free radicals overwhelms the protective capability of antioxidant defense system [23]. Both enzymatic and non-enzymatic antioxidant systems exist to combat oxidative stress under physiological conditions [24-26].

Antioxidant enzymes such as catalase, SOD, glutathione peroxidase (GPx), glutathione reductase (GR), as well as molecule such as GSH are used as indices of oxidative stress [27-30]. Studies have shown that accumulated oxidative damage occurs from decreased levels of these enzymes rather than increased ROS production [31,32]. However, adequate levels of both are vital for normal cell function. Kidney, an organ that metabolizes harmful substances besides liver, is constantly perfused with huge volume of blood carrying different kinds of compounds, thereby making it at high risk of toxicity [33,34]. High levels of blood creatinine are found in renal dysfunction or muscle injury [35]. Levels of specific ions such as sodium $(\mathrm{Na}+)$, potassium $(\mathrm{K}+)$, chloride $(\mathrm{Cl}-)$ and bicarbonate (HCO3-) are used as biomarkers of electrolyte imbalance [36]. Electrolytes promote fluid balance via maintenance of blood volume, fluid absorption and generation of impulses.

In pathological conditions, electrolyte imbalance occurs with increased sodium and chloride, and decreased potassium levels $[37,38]$. Nephrotoxicity is characterized by morphological destruction of intracellular organelles, necrosis, and functional alterations such as depletion of antioxidant defense system and mitochondrial damage [39]. Oxidative damage is thought to be one of the major mechanisms involved in nearly all chronic renal pathologies [40-42]. Reports on the beneficial effects of $C$. lanatus seed abound, but little or nothing is known about its nephrotoxic effect. This study investigated the nephrotoxic and in vivo antioxidant effects of $C$. lanatus seed extract.

\section{Materials and Methods}

\section{Chemicals and Reagents}

All reagents used were of analytical grade. Electrolytes assay kits were products of Randox Laboratories Limited (UK). All other chemicals were obtained from British Drug House (BDH) (England), Merck (Germany) and Sigma-Aldrich Chemical Company (USA).

\section{Plant Sample Collection}

Citrullus lanatus seeds were obtained from a major market in Benin City, Edo State, Nigeria, and authenticated at the herbarium of the Department of Plant Biology and Biotechnology, University of Benin, Benin City, Nigeria.

\section{Plant Preparation and Extraction}

Plant seeds were washed and shade-dried at room temperature for a period of two weeks and pulverized using a mechanical blender. Methanol extract of the seeds was obtained using cold maceration method. Exactly $2 \mathrm{~kg}$ of powdered seeds was extracted with $5 \mathrm{~L}$ of absolute methanol for $96 \mathrm{~h}$ with intermittent stirring. The extract was concentrated using rotary evaporator and freezedried via lyophilization.

\section{Experimental Rats}

Adult male Wistar rats $(\mathrm{n}=35)$ weighing $130-170 \mathrm{~g}$ (mean weight $=150 \pm 20 \mathrm{~g}$ ) were obtained from the Department of Anatomy, University of Benin, Benin City. The rats were housed in metal cages under standard laboratory conditions: average temperature of $25{ }^{\circ} \mathrm{C}, 55-65 \%$ humidity and 12-h light/12-h dark cycles. They were allowed access to rat feed (pelletized growers mash) and clean drinking water. Prior to commencement of the study, the rats were acclimatized to the laboratory environment for one week. The study protocol was approved by the Faculty of Life Sciences, University of Benin, Ethical Committee on Animal Use.

\section{Experimental Design}

The rats were randomly assigned to 7 groups ( 5 rats/group): normal control, Tween 80 control, and five treatment groups. Tween 80 was used to solubilize the extract before administration. Rats in the treatment groups received graded doses of the extract (10 - $5000 \mathrm{mg} / \mathrm{kg}$ bwt) orally for 35 days.

Collection of Blood and Tissue Samples: At the end of the treatment period, the rats were anaesthetized with chloroform vapor. Blood samples were drawn from each rat heart via cardiac puncture into heparin containers and centrifuged at $3000 \mathrm{rpm}$ for 10 min to obtain plasma which was used for biochemical analysis. The kidneys were excised, weighed and used to prepare $20 \%$ tissue homogenate.

Biochemical Analysis: Kidney function parameters (creatinine, urea and electrolytes) and levels of GSH and MDA, and activity of SOD were determined using their respective assay kits.

\section{Statistical Analysis}

Data are expressed as mean \pm SEM. Statistical analysis was performed using SPSS (21.0). Groups were compared using Student t-test. Statistical significance was assumed at $\mathrm{p}<0.05$.

\section{Results}

\section{Effect of Methanol Extract of C. lanatus Seed on Body and Organ Weights of Rats}

The absolute and relative weights of kidneys of rats in each group were not significantly affected by extract treatment ( $\mathrm{p}>$ 0.05). There were significant increases in the final body weight and percentage weight increase in the treatment groups, relative to normal control group $(\mathrm{p}<0.05)$. These results are shown in (Tables $1 \& 2)$. 
Table 1: Changes in Body Weight of Rats Administered Methanol Extract of C. lanatus Seed.

\begin{tabular}{|c|c|c|c|}
\hline Group & Final Weight (g) & Initial Weight (g) & Increase in Weight (g) \\
\hline Normal control & $167.20 \pm 6.73$ & $139.80 \pm 4.58$ & $27.40 \pm 4.37 \mathrm{a}$ \\
\hline Tween 80 control & $228.60 \pm 5.51$ & $159.60 \pm 2.01$ & $69.00 \pm 3.65 \mathrm{~b}$ \\
\hline $10 \mathrm{mg}$ extract/kg bwt & $221.40 \pm 8.76$ & $145.60 \pm 7.55$ & $75.80 \pm 2.03 \mathrm{~b}$ \\
\hline $100 \mathrm{mg}$ extract/kg bwt & $221.00 \pm 10.04$ & $130.80 \pm 9.81$ & $79.20 \pm 2.71 \mathrm{~b}$ \\
\hline $1000 \mathrm{mg}$ extract/ $\mathrm{kg} \mathrm{bwt}$ & $231.40 \pm 9.34$ & $153.20 \pm 7.93$ & $78.20 \pm 2.75 \mathrm{~b}$ \\
\hline $2000 \mathrm{mg}$ extract/kg bwt & $235.20 \pm 10.37$ & $157.20 \pm 11.60$ & $78.00 \pm 0.45 \mathrm{~b}$ \\
\hline $5000 \mathrm{mg}$ extract/kg bwt & $235.40 \pm 11.41$ & $148.40 \pm 11.41$ & $77.00 \pm 3.92 \mathrm{~b}$ \\
\hline
\end{tabular}

Note: Data are reported as mean \pm SEM $(n=5)$. The values with different superscript within the same row or column showed significant differences $(\mathrm{p}<0.05)$.

Table 2: Relative organ to body weight of rats administered methanol extract of $C$. lanatus seed.

\begin{tabular}{|c|c|c|c|}
\hline Group & Kidney Weight $(\mathbf{g})$ & Final Body Weight (g) & Kidney Weight/Body Weight \\
\hline Normal control & $0.53 \pm 0.03$ & $167.20 \pm 6.37$ & $3.20 \pm 0.23$ \\
\hline Tween 80 control & $0.64 \pm 0.03$ & $228.60 \pm 5.51 \mathrm{a}$ & $2.80 \pm 0.19$ \\
\hline $10 \mathrm{mg}$ extract/kg bwt & $0.65 \pm 0.04$ & $221.40 \pm 8.76 \mathrm{a}$ & $3.50 \pm 0.73$ \\
\hline $100 \mathrm{mg}$ extract/kg bwt & $0.68 \pm 0.07$ & $210.00 \pm 10.04 \mathrm{a}$ & $3.30 \pm 0.45$ \\
\hline $1000 \mathrm{mg}$ extract/ $\mathrm{kg}$ bwt & $0.61 \pm 0.06$ & $231.40 \pm 9.34 \mathrm{a}$ & $2.60 \pm 0.12$ \\
\hline $2000 \mathrm{mg}$ extract/kg bwt & $0.63 \pm 0.02$ & $235.20 \pm 10.73 \mathrm{a}$ & $2.70 \pm 0.16$ \\
\hline $5000 \mathrm{mg}$ extract/kg bwt & $0.65 \pm 0.47$ & $225.40 \pm 11.41 \mathrm{a}$ & $2.90 \pm 0.34$ \\
\hline
\end{tabular}

Note: Data are expressed as mean \pm SEM $(n=5)$. Values with superscript (a) differ significantly from the normal control value $(p<$ $0.05)$.

\section{Effect of Methanol Extract of C. lanatus Seed on Levels of Electrolytes}

Methanol extract of $C$. lanatus seed did not significantly alter the levels of electrolytes and creatinine ( $p>0.05)$. Moreover, Tween 80 significantly increased the levels of bicarbonate ion, urea and urea/creatinine ratio $(p<0.05$; Tables 3 and 4).

Table 3: Effect of Methanol Extract of C. lanatus Seed on Levels of Electrolytes.

\begin{tabular}{|c|c|c|c|c|}
\hline Group & \multicolumn{4}{|c|}{ Parameter } \\
\hline & $\mathrm{Na}+(\mu \mathrm{M})$ & $\mathrm{K}+(\mu \mathrm{M})$ & $\mathrm{HCO3}-(\mu \mathrm{M})$ & $\mathrm{Cl}-(\mu \mathrm{M})$ \\
\hline Normal control & $140.00 \pm 3.51$ & $7.90 \pm 0.35$ & $14.67 \pm 1.36$ & $102.67 \pm 2.60$ \\
\hline Tween $80 \mathrm{control}$ & $140.00 \pm 0.58$ & $7.89 \pm 0.96$ & $22.33 \pm 1.76 \mathrm{a}$ & $103.67 \pm 1.20$ \\
\hline $10 \mathrm{mg}$ extract/kg bwt & $135.00 \pm 4.04$ & $5.37 \pm 0.32$ & $20.00 \pm 1.15 \mathrm{a}$ & $99.00 \pm 4.04$ \\
\hline $100 \mathrm{mg}$ extract/kg bwt & $135.00 \pm 3.79$ & $6.73 \pm 0.90$ & $21.00 \pm 1.53 \mathrm{a}$ & $101.00 \pm 4.16$ \\
\hline $1000 \mathrm{mg}$ extract/ kg bwt & $139.33 \pm 1.20$ & $8.70 \pm 0.60$ & $22.33 \pm 1.45 \mathrm{a}$ & $106.00 \pm 1.15$ \\
\hline $2000 \mathrm{mg}$ extract/kg bwt & $145.33 \pm 4.41$ & $6.70 \pm 0.96$ & $21.00 \pm 1.15 \mathrm{a}$ & $106.67 \pm 3.53$ \\
\hline $5000 \mathrm{mg}$ extract/kg bwt & $142.33 \pm 1.33$ & $8.20 \pm 0.93$ & $21.00 \pm 1.00 \mathrm{a}$ & $106.67 \pm 1.86$ \\
\hline
\end{tabular}

Note: Data are levels of electrolytes and are expressed as mean \pm SEM $(n=5)$. Values with superscript $(a)$ differ significantly from the normal control value $(\mathrm{p}<0.05)$.

Table 4: Effect of Methanol Extract of C. lanatus Seed on Levels of Urea and Creatinine.

\begin{tabular}{|c|c|c|c|}
\hline Group & Urea $(\mathbf{m g} / \mathbf{d L})$ & Parameter Creatinine (mg/dL) & Urea/ Creatinine \\
\hline Normal control & $37.67 \pm 3.38$ & $0.83 \pm 0.03$ & $45.39 \pm 3.11$ \\
\hline Tween 80 control & $50.00 \pm 2.65 \mathrm{a}$ & $0.83 \pm 0.20$ & $60.24 \pm 3.09 \mathrm{a}$ \\
\hline $10 \mathrm{mg}$ extract/kg bwt & $44.00 \pm 1.53 \mathrm{a}$ & $0.77 \pm 0.15$ & $57.14 \pm 2.01 \mathrm{a}$ \\
\hline $100 \mathrm{mg}$ extract/kg bwt & $50.00 \pm 6.11 \mathrm{a}$ & $1.00 \pm 0.10$ & $50.00 \pm 0.80 \mathrm{a}$ \\
\hline $1000 \mathrm{mg}$ extract/ $\mathrm{kg}$ bwt & $48.00 \pm 3.46 \mathrm{a}$ & $0.77 \pm 0.09$ & $62.34 \pm 2.16 \mathrm{a}$ \\
\hline $2000 \mathrm{mg}$ extract/kg bwt & $51.67 \pm 3.71 \mathrm{a}$ & $0.83 \pm 0.15$ & $62.25 \pm 2.81 \mathrm{a}$ \\
\hline $5000 \mathrm{mg}$ extract/kg bwt & $47.67 \pm 2.73 \mathrm{a}$ & $1.00 \pm 0.00$ & $47.67 \pm 1.01$ \\
\hline
\end{tabular}

Note: Data are renal function indices and are expressed as mean \pm SEM $(n=5)$. Values with superscript (a) differ significantly from the normal control value $(\mathrm{p}<0.05)$. 


\section{Effect of Methanol Extract of $C$. lanatus Seed on Oxidative Status of Normal Rats}

There were no significant differences in MDA and GSH levels and activity of SOD among the groups ( $p>0.05$; Table 5).

Table 5: Effect of Methanol Extract of C. lanatus Seed on Oxidative Status of Normal Rats.

\begin{tabular}{|c|c|c|c|}
\hline Group & $\begin{array}{c}\text { MDA } \\
\text { (mole/mg protein) } \mathbf{x 1 0} \mathbf{- n}^{-5}\end{array}$ & $\begin{array}{c}\text { Parameter } \\
\text { GSH (mg/dL) }\end{array}$ & $\begin{array}{c}\text { SOD } \\
\text { (unit/mg protein) x10 }\end{array}$ \\
\hline Normal control & $8.90 \pm 1.30$ & $17.17 \pm 0.05$ & $1.20 \pm 0.09$ \\
\hline Tween 80 control & $6.50 \pm 1.10$ & $15.02 \pm 0.41$ & $2.10 \pm 0.06$ \\
\hline $10 \mathrm{mg}$ extract/kg bwt & $5.70 \pm 4.80$ & $16.30 \pm 0.37$ & $1.40 \pm 0.09$ \\
\hline $100 \mathrm{mg}$ extract/kg bwt & $7.10 \pm 0.57$ & $16.45 \pm 0.34$ & $1.80 \pm 0.06$ \\
\hline $1000 \mathrm{mg}$ extract/ $\mathrm{kg}$ bwt & $8.60 \pm 2.10$ & $17.27 \pm 0.82$ & $1.60 \pm 0.03$ \\
\hline $2000 \mathrm{mg}$ extract/kg bwt & $6.00 \pm 1.00$ & $17.08 \pm 0.61$ & $0.90 \pm 0.02$ \\
\hline $5000 \mathrm{mg}$ extract/kg bwt & $5.30 \pm 3.50$ & $15.58 \pm 0.23$ & $0.94 \pm 0.04$ \\
\hline
\end{tabular}

Note: Data are oxidative stress markers and are expressed as mean \pm SEM $(n=5)$.

\section{Discussion}

Electrolyte balance is crucial for normal cellular function. Electrolytes promote fluid balance via maintenance of blood volume, facilitation of fluid absorption and generation of impulses. Decreased electrolyte levels affects nerve conduction, as well as cell function [37]. Blood urea and creatinine are considered traditional indices of kidney function. Urea is a by-product of protein catabolism. About $90 \%$ of urea produced is excreted through the kidneys [41]. Creatinine, a waste product of muscle catabolism, is excreted exclusively via the kidneys [42]. Therefore, renal damage reduces the kidney's capacity to excrete both urea and creatinine, thereby making them to accumulate in the blood. The results of this study showed that methanol extract of $C$. lanatus seed did not significantly alter the levels of electrolytes and creatinine. The observed increases in the levels of bicarbonate ion, urea and urea/creatinine ratio may have been due to Tween 80 that was used to solubilize the extract. Free radical generation leads to lipid peroxidation that causes renal injury [12]. Anti-oxidation is a significant event used as a preventive strategy against diseases [13].

Antioxidant enzymes such as catalase, SOD, GPx, GR, as well as molecule such as GSH are used as indices of oxidative stress [2730]. Studies have shown that accumulated oxidative damage occurs from decreased levels of these enzymes rather than increased ROS production [31,32]. Superoxide Dismutase (SOD) catalyzes the dismutation of superoxide anion [24]. Therefore, marked reduction in its activity produces several deleterious effects due to accumulation of superoxide anion. Reduced Glutathione (GSH) is vital for recycling of cellular antioxidants, suppression of free radical-induced damage, detoxification of harmful compounds, as well as maintenance of redox status of the cell [43]. Increased GSH level protects tissues against organ-associated injury via reduction in susceptibility to toxic radicals [44]. Extracts of plants have been reported to potentiate the activity and level of SOD and GSH, respectively $[45,46]$. Malondialdehyde (MDA) is a commonly used index of lipid peroxidation [22]. In this study, there were no significant differences in the levels of GSH and MDA, and activity of SOD among the groups, an indication that methanol extract of C. lanatus seed may not alter the redox status of the cell in normal Wistar rats. The absolute and relative weights of kidneys of rats in each group were not significantly affected by extract treatment. Moreover, there were significant increases in the final body weight and percentage weight increase in the test groups when compared with the normal control group. The increase was not dose-depended on and may be attributed to Tween 80 .

\section{Conclusion}

The results obtained in this study show that methanol extract of Citrullus lanatus seed is not nephrotoxic and possesses high antioxidant activity in vivo.

\section{References}

1. Kiin Kabari DB, Akusu OM (2014) Effect of processing on the proximate composition, functional properties and storage stability of watermelon (Citrullus lanatus) seed flour. Int J Biotechnol Food Sci 2(7): 143-148.

2. Seidu KT, Osundahunsi, OF, Olaleye, MT, Oluwalana IB (2015) Amino acid composition, mineral contents and protein solubility of some lima bean (Phaseolus lunatus L. Walp) seeds coat. Food Res Int 73: 130-134.

3. Salgado JM, Rodrigues BS, Donado Pestana CM, Morzelle MC, dos Santos Dias CT (2011) Cupuassu (Theobroma grandiflorum) peel as potential source of dietary fiber and phytochemicals in whole-bread preparations. Plant Foods Hum Nutr 66(4): 384-390.

4. Braide W, Odiong IJ, Oranusi S (2012) Phytochemical and Antibacterial properties of the seed of watermelon (Citrullus lanatus). Prime Journal of Microbiology Research 2(3): 99-104.

5. Jensen BD, Toure FM, Hamattal MA, Toure FA, Nantoumé DA (2011) Wtermelons in the Sand of Sahara: Cultivation and use of indigenous landraces in the Tombouctou Region of Mali. Ethnobotany Research and Applications 9: 151-162.

6. Reamakers HR (2001) Crop production in the Tropical regions. DGIT Ministry of foreign affairs, external trade and international cooperation, Brussels, Belgium pp. 475-479.

7. Madhavi P, Maruthi R, Kamala V, Habibur R, Chinna E (2012) Evaluation of Anti-inflammatory Activity of Citrullus lanatus Seed Oil by In-vivo and In-vitro Models. Int Res J Pharm App Sci 2(4): 104-108. 
8. Alok B, Rajeev K, Vivek D, Niyaz A (2012) Evaluation of Anti-ulcer Activity of Citrullus lanatus Seed Extract in Wister Albino Rats. International Journal of Pharmacy and Pharmaceutical Sciences 4(5): 135-139.

9. Naresh SG (2011) Evaluation of Antioxidant Activity of Citrullus lanatus Seed Extract in Rats. Lat Am J Pharm 30(3): 429-434.

10. Yamagishi S, Matsui T (2011) Nitric oxide, a Janus-faced therapeutic target for diabetic microangiopathy - friend or foe? Pharmacol Res 64: 187-194.

11. Barbagallo M, Marotta F, Dominguez LJ (2015) Oxidative stress in patients withAlzheimer's disease: effect of extracts of fermented papaya powder. Mediators Inflamm 2015: 1-6.

12. Guo C, McMartin KE (2005) The cytotoxicity of oxalate, metabolite of ethylene glycol, is due to calcium oxalate monohydrate formation. Toxicology 208(3): 347-355.

13. Motawi TK, Hamed MA, Shabana MH, Hashem RM, Aboul Naser AF (2011) Zingber officinale acts as a nutraceutical agent against liver fibrosis. Nutr Met 8: 40.

14. Bors W, Michel C, Stettmaier K (2001) Structure-activity relationships governing antioxidant capacities of plant polyphenols. Methods Enzymol 335: 166-180.

15. Yildrim A, Mavi A, Oktay M, Kara AA, Algur OF, et al. (2000) Comparison of antioxidant and antimicrobial activities of Tilia (Tilia argentea Desf Ex DC), Sage (Savia trilobia L.) and black tea (Camella sinensis) extracts. J Agric Food Chem 48(10): 5030-5034.

16. Wanasundara UN, Shahidi F (1998) Antioxidant and pro-oxidant activity of green tea extracts in marine oils. Food Chem 63: 335-342.

17. Rafieian Kopaei M (2013) Medicinal plants for renal injury prevention. J Renal Inj Prev 2: 63-65.

18. Prior RL, Cao G (2000) Analysis of botanicals and dietary supplements for antioxidant capacity: a review. J AOAC Int 83(4): 950-956.

19. Halliwell B, Gutteridge J (1999) Free radicals in biology and medicine. $3^{\text {rd }}$ edn. Oxford: Oxford University Press pp. 23-27.

20. Irshad M, Chaudhuri PS (2002) Oxidant-antioxidant system: role and significance in human body. Indian J Exp Biol 40: 1233-1239.

21. Sen S, Chakaraborty R, Sridhar C, Reddy Y, Biplab D (2010) Free radicals, antioxidants, diseases and phytomedicines: current status and future prospect. Int J Pharm Sci Rev Res 3(1): 91-100.

22. Ma J, Qiao Z, Xiang X (2011) Aqueous extract of Astragalus mongholicus ameliorates high cholesterol diet induced oxidative injury in experimental rats' models. J Med Plants Res 5: 855-858.

23. Edeoga HO, Okwu DE, Mbaebie BO (2005) Phytochemical constituents of some Nigerian medicinal plants. Afr J Biotech 4: 685-688.

24. Medina J, Moreno Otero R (2005) Pathophysiological basis for antioxidant therapy in chronic liver disease. Drugs 65(17): 2445-2461.

25. Dey A, Lakshmanan J (2013) The role of antioxidants and other agents in alleviating hyperglycemia mediated oxidative stress and injury in liver Food Funct 4: 1148-1184.

26. Karabulut AB, Gui M, Karabulut E, Kiran TR, Ocak SG, et al. (2010) Oxidant and antioxidant activity in rabbit livers treated with zoledronic acid. Transplant. Proc 42: 3820-3822.

27. Mallikarjuna K, Shanmugam KR, Nishanth K, Wu MC, Hou CW, et al (2010) Alcohol-induced deterioration in primary antioxidant and glutathione family enzymes reversed by exercise training in the liver of old rats. Alcohol 44(6): 523-529.

28. Gomes P, Simao S, Silva E, Pinto V, Amaral JS, et al. (2009) Aging increases oxidative stress and renal expression of oxidant and antioxidant enzymes that are associated with an increased trend in systolic blood pressure. Oxid Med Cell Longev 2(3): 138-145.
29. Pias EK, Aw TY (2002) Apoptosis in mitotic competent undifferentiated cells is induced by cellular redox imbalance independent of reactive oxygen species production. FASEB J 16(8): 781-790.

30. Zhuang S, Yan Y, Daubert RA, Han J (2007) ERK promotes hydrogen peroxide- induced apoptosis through caspase-3 activation and inhibition of Akt in renal epithelial cells. Am J Physiol Renal Physiol 292(1): F440-F447

31. Kokoszka JE, Coskun P, Esposito LA, Wallace DC (2001) Increased mitochondrial oxidative stress in the SOD2 (+/-) mouse results in the age-related decline of mitochondrial function culminating in increased apoptosis. Proc Natl Acad Sci 98(5): 2278-2283.

32. Meng Q Wong YT, Chen J, Ruan R (2007) Age-related changes in mitochondrial function and antioxidative enzyme activity in fischer 344 rats. Mech Ageing Dev 128 (3): 286-292.

33. Tortora GJ, Derrickson B (2006) Liver and gallbladder. In Principle of Anatomy and Physiology, $11^{\text {th }}$ edn. United States of America: John Wiley and Sons, Inc pp. 918-921.

34. Small DM, Coombes JS, Bennett N, Johnson DW (2012) Oxidative stress, antioxidant therapies and chronic kidney disease. Nephrology 17(4): 311-321.

35. Sodipo OA, Abdulrahman FI, Sandabe UK (2012) Biochemical kidney function with aqueous fruit extract of Solanum macrocarpum (Linn) in albino rats chronically administered triton-X to induce hyperlipidemia. AJMMS 3(2): 93-98.

36. Bheeman D, Mathan R, Rama KP (2013) Effect of ammonia on the electrolyte status of an Indian major carp Catla catla. Aquacult Res 44(11): 1677-1684

37. Feroz Z, Khan RA, Afroz S (2009) Effect of multiple drug administration on gross toxicities and electrolytes. Pak J Pharmacol 26(2): 33-39.

38. Baniata A, Manse K, Aburjai T, Aburjai S, Al Gazzawi M (2009) Biochemical factors relevant to kidney functions among Jordanian top athletes. Sci Res Essay 4(5): 426-431.

39. Joy J, Nair CK (2008) Amelioration of cisplatin induced nephrotoxicity in Swiss albino mice by Rubia cordifolia extract. J Cancer Res Ther 4(3): 111-115.

40. Wojcikowski K, Stevenson L, Leach D, Wohlmuth H, Gobe G (2007) Antioxidant capacity of 55 medicinal herbs traditionally used to treat the urinary system: A comparison using a sequential three-solvent extraction process. J Altern Complement Med 13(1): 103-109.

41. Walmsley SJ, Broeckling C, Hess A, Prenni J, Curthoys NP (2010) Proteomic analysis of brush-border membrane vesicles isolated from purified proximal convoluted tubules. Am J Physiol Renal Physiol 298(6): F1323-F1331.

42. Treasure J (2003) Urtica semen reduces serum creatinine levels. J Am Herbal Guild 4(2): 22-25.

43. Sen CK (1997) Nutritional Biochemistry of cellular glutathione. Journal of Nutritional Biochemistry 8(12): 660-672.

44. Inove M, Salto Y, Hirato E, Morino Y, Nagase S (1987) Regulation of relax status of plasma by metabolism and transport of glutathione and related compounds. Journal of Protein Chemistry 36: 136-173.

45. Abu OD, Onoagbe IO (2019) Biochemical effect of aqueous extract of Dialium Guineense stem bark on oxidative status of normal Wistar rats. International Journal of Clinical Biology and Biochemistry 1(2): 15-18.

46. Abu OD, Imafidon KE, Iribhogbe ME (2015) Biochemical effect of aqueous leaf extract of Icacina trichanta Oliv. on urea, creatinine and kidney oxidative status in CCl4-induced Wistar rats. Nigerian Journal of Life Sciences 5(1): 85-89. 
ISSN: 2574-1241

DOI: 10.26717/BJSTR.2021.33.005473

Abu Osahon Daniel. Biomed J Sci \& Tech Res

(C) (P) This work is licensed under Creative

Submission Link: https://biomedres.us/submit-manuscript.php

$\begin{array}{ll}\text { BIOMEDICAL } & \text { Assets of Publishing with us } \\ \text { RESEARCHES } & \text { Global archiving of articles } \\ \text { - Immediate, unrestricted online access } \\ \text { - Rigorous Peer Review Process }\end{array}$

